\title{
A bioarchaeological investigation of a multiple burial associated with the Batavia mutiny of 1629
}

\author{
D. Franklin and L. Freedman \\ School of Anatomy and Human Biology, University of Western Australia, \\ Crawley, Western Australia 6009, Australia
}

\begin{abstract}
On 29 October 1628, the Verenigde Oostindische Compagnie (VOC) Retourschip Bataria embarked on a voyage into infamy. Originally sailing as part of a fleet of six other ships, the Batarin was subsequently separated, and wrecked on Morning Reef in the Houtman Abrolhos on 4 June 1629. The ship's Commander, Francisco Pelsaert, had survivors landed on nearby Beacon Island, and then embarked on a rescue voyage to Batavia (modern day Jakarta). During Pelsaert's absence, an ultimately unsuccessful mutiny attempt resulted in the murder of at least 125 people.

Human skeletal material has been recovered from excavations of the Bataria land sites since the 1960s. Four individual burials were discovered between 1960 and 1964. A further six individuals were recovered from a multiple burial between 1994 and 2001. Characteristics of the multiple burial, such as the age, sex, positioning of individuals interred and evidence of trauma are analysed and compared for any similarity to individuals listed, and events outlined and historically recorded. The results of this analysis suggest that four of the interred are probably the sick individuals who were amongst the massacre's early victims; two sub-adults were also included in the burial, at least one of which can also be directly accounted for.
\end{abstract}

\section{INTRODUCTION}

The Verenigde Oostindische Compagnie (VOC) ship Retourschip Batawio was one of the largest and finest armed vessels of the time. Carrying a complement of approximately 316 people, the Bataria embarked from Amsterdam on 29 October 1628, destined for Batavia (modern day Jakarta). Cramped on board were men, women and children of various socio-economic backgrounds and nationalities, including VOC officers and crew, in addition to naval cadets, passengers and soldiers (Drake-Brockman 1963; Tyler 1970). Originally sailing alongside a fleet of six other ships, the Bataila was subsequently separated, and wrecked on Morning Reef in the Houtman Abrolhos off Australia's west coast on 4 June 1629 (Figure 1) (Drake-Brockman 1963; van Huystee 1998). According to historical records, the exact events leading to the separation of the Batavin from the fleet and her subsequent grounding remain somewhat speculative.

Unable to free the Batawio from Morning Reef, the ship's Commander, Francisco Pelsaert had 180 survivors landed on nearby Beacon Island, a small coral island lacking freshwater (Figure 1). About another 40 people (Pelsaert included) were landed on one of the smaller islands early the following morning, leaving approximately 70 to 80 survivors on the ship (Tyler 1970). Of those people still aboard, approximately 40 were reported to have drowned attempting to swim from the wreck to land (van Huystee 1998). The exact figures are unclear, but Drake-Brockman (1963: 50) puts the total number finally landed at 268 . Knowing that their situation was dire, Pelsaert decided to take a group in search of water on nearby islands and the main 'Southland' (Drake-Brockman 1963: 126-127). Failing in their search, Pelsaert resolved to attempt the hazardous voyage of more than 1900 kilometres to Batavia (Drake-Brockman 1963).

Prior to the wrecking of the Batavia, trouble between the ship's skipper, Adriaen Jacobsz, the undermerchant, Jeronimus Cornelisz and Pelsaert had sowed the seeds of dissent, which escalated on the island into a plan for mutiny (see DrakeBrockman 1963: 35-60). So, while Pelsaert attempted the perilous rescue voyage to Batavia, Cornelisz remained on Beacon Island and managed to establish his own 'ruling council', and with the aid of his followers began to murder all who opposed him. Cornelisz planned to reduce the total number of survivors to 40 , with whom he planned to hijack the anticipated rescue ship. Before Pelsaert's return, Cornelisz and his accomplices had murdered at least 125 men, women and children.

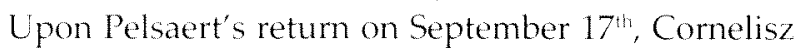
and his accomplices were captured, tried and most were duly executed on purpose-built gallows erected on Seals Island (present day Long Island) (Drake-Brockman 1963). 


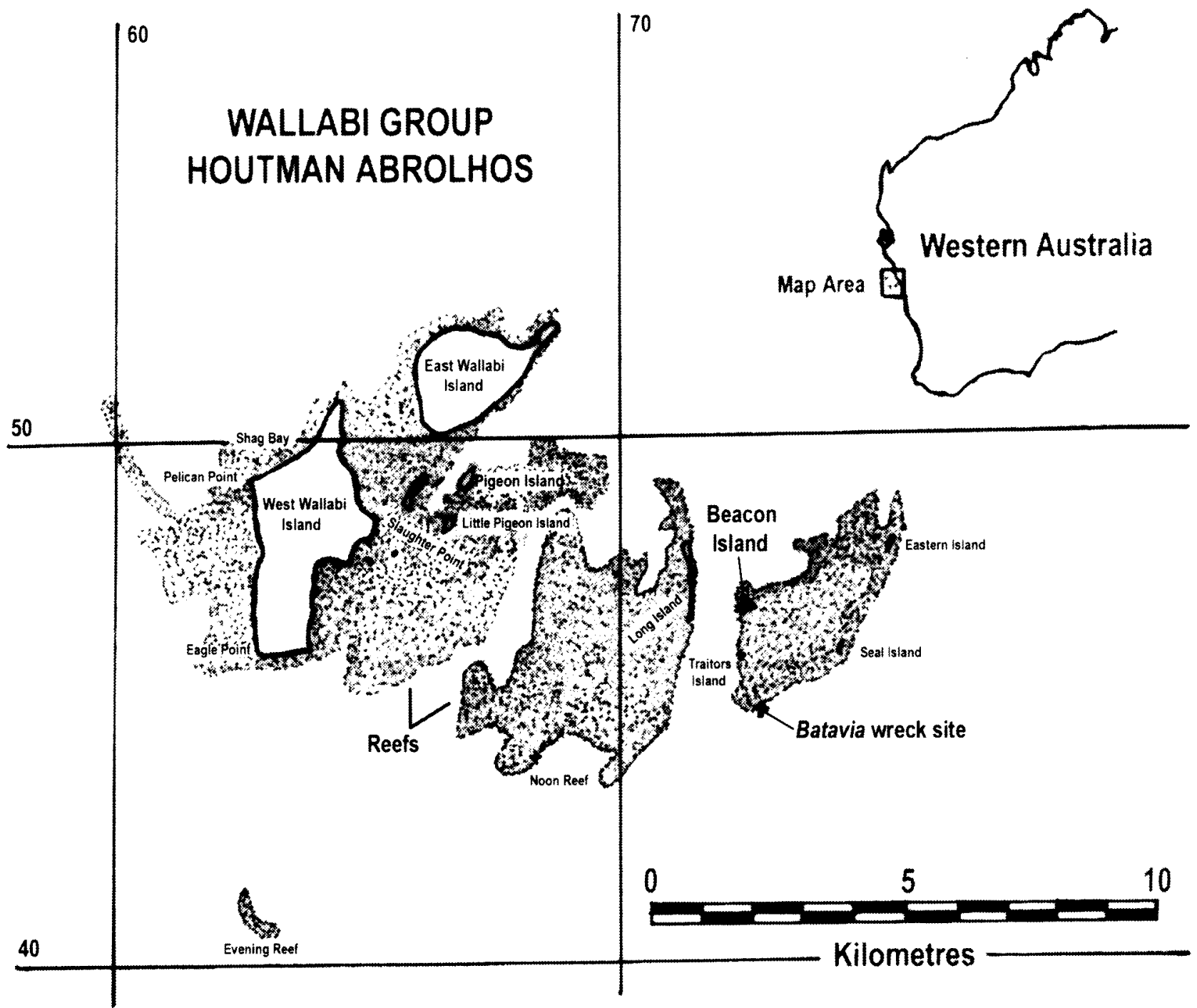

Figure 1 Wallabi Group, Houtman Abrolhos Islands, showing locations of East and West Wallabi Islands, Beacon Island (A) and the Batavia shipwreck (+) location (adapted from Green 1989).

So far, the skeletal remains of ten individuals have been found on Beacon Island. Four individual burials were discovered between 1960 and 1964 (Stanbury 1998). A further six individuals were recovered from a multiple grave between 1994 and 2001. All are believed to be victims of the slaughter. Some brief descriptions of the multiple grave material have been made by Hunneybun (1995), Pasveer et al. (1998) and Pasveer (2000). The purpose of this paper is to present a description and interpretation (using forensic, archaeological and historical sources) of the human skeletal material recovered from the multiple burial. Age, sex, stature, general state of health and trauma will be assessed and an attempt made to identify the recovered individuals.

The primary source of information documenting the epic voyage of the Batavia, the wrecking of the ship and the trials of the mutineers is the manuscript 'Droevige daghaenteyckeningh int verliesen van ons schip Batavia', usually known as the 'Pelsaert Journal' (van Huystee 1998).

\section{THE SITE}

The Houtman Abrolhos lie approximately $65 \mathrm{~km}$ off the west coast of Australia, between latitudes $28^{\circ}$ and $29^{\circ}$ south (Figure 1 ). The Abrolhos are four well-distinguished geographical units: North Island and the Wallabi, Easter and Pelsaert Island Groups (Teichert 1946). The Wallabi Group is the northernmost in the Abrolhos, consisting of 32 islands scattered over an extensive system of coral reefs. The elevation of the islands is generally low, mostly approximately 2.5 metres above sea level (Dakin 1919). The eastern islands, such as Beacon and Long, are considerably smaller and consist of accumulations of coral boulders and shingles (Storr 1965). Beacon Island, with an approximate area of 5.25 hectares, is sparsely vegetated and without a source of fresh water (Bevacqua 1974; Green and Stanbury 1988).

\section{EXCAVATION}

A review of the research directly concerning the 
discovery of the multiple burials on Beacon Island follows.

\section{Field Season}

In 1993, Philippe Godard reported John Gliddon's discovery of a skeleton while digging a hole for a 'septic tank' near his house in 1990 (Figure 2) (Godard 1993: 237). The concern for further damage by souvenir hunters, due to the relatively precise location provided by Godard, supported by Gliddon's declaration under the Commonwealth Historic Shipwrecks Amnesty (1993-1994), provided the impetus for the 1994 field season by the Western Australian Maritime Museum. This season aimed to investigate the nature and extent of the disturbance to the burial site based upon interviews with residents of Beacon Island and to make a physical investigation of the area (Gibbs 1994).

Gibbs established that the trench dug for piping associated with a nearby toilet (leach drain) had been constructed possibly six years earlier (around 1988) and that at least two or three skeletons were found. One of the workers removed at least one skull and mandible (Gibbs 1994). New sites were identified along the southern edge of the house and excavation in $1 \mathrm{~m}$ squares followed (Figure 2). In the absence of detectable stratigraphic changes, arbitrary levels of 5 or $10 \mathrm{~cm}$ were removed. Bulk samples were collected, $\mathrm{pH}$ and Munsell soil colours recorded and all material sieved through three and five millimetre nested screens (Gibbs 1994).

The excavation area was extended in the hope of

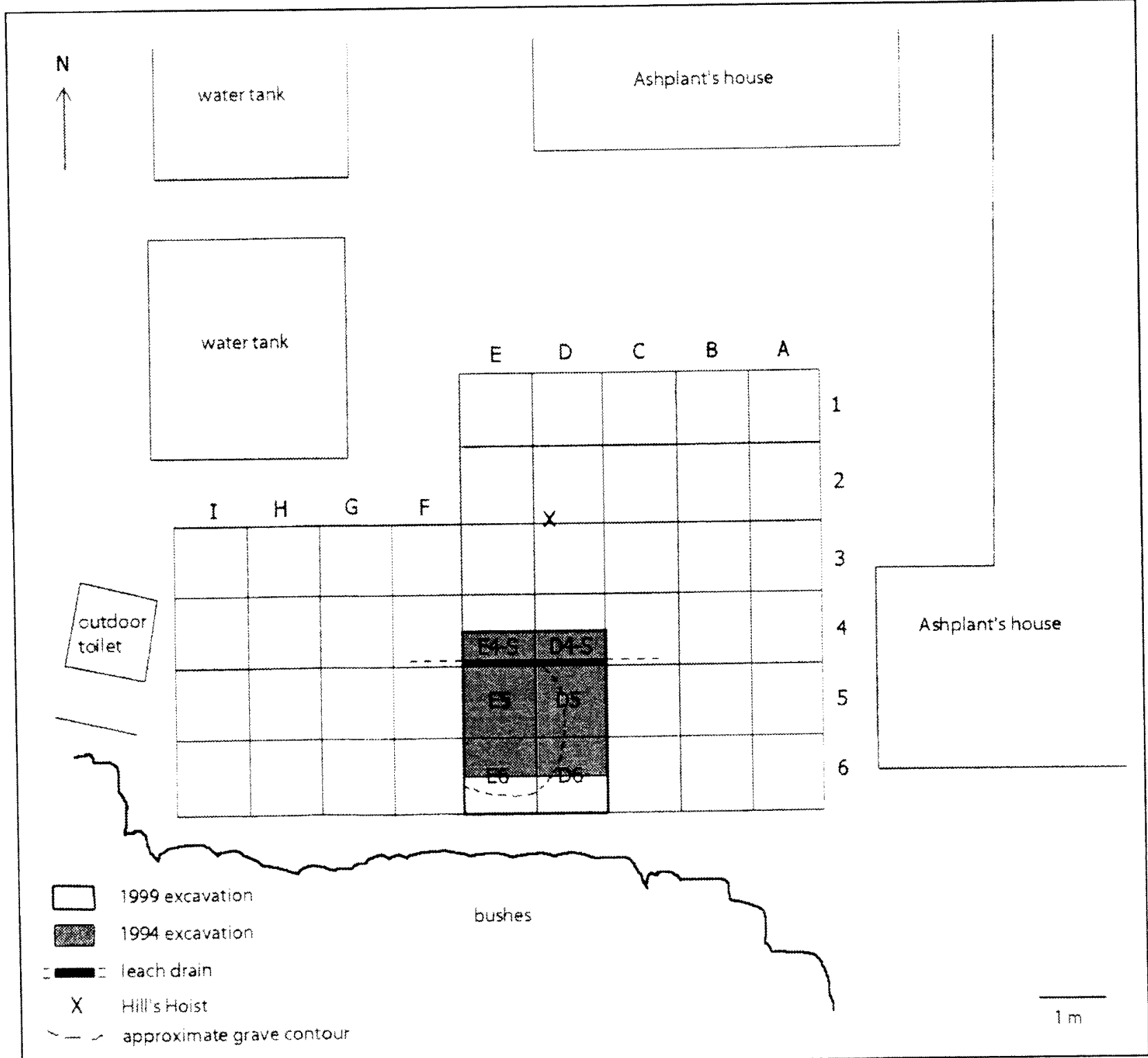

Figure 2 Site map showing the excavated area (from Pasveer 2000). The house currently occupied by the Ashplant family was formerly occupied by John Gliddon. 
finding more bone fragments, leading to the location of the remaining in-situ skeletal remains. The two squares chosen for detailed examination (E5 and D5 - Figure 2) were found to contain two skulls (one of which was significantly damaged) situated side by side with several other large adult bone fragments (Gibbs 1994). The skeletons appeared to extend south from the region of the skulls. During excavation there were no discernable stratigraphic changes and the soil $\mathrm{pH}$ ranged between 8.5 and 10 . Bone fragments were evident from the first level and a maximum depth of $35 \mathrm{~cm}$ was reached during excavation (Gibbs 1994; Hunneybun 1995).

It was concluded that two skeletons were present in the site and were disturbed during the toilet sump and leach drain construction (Pasveer 2000: 5). Two adult crania (SK5 and SK6) were identified; fragments of SK5 were recovered for analysis and SK6 was left in situ (Stanbury 1998; Pasveer 2000). The stratigraphy of the test pits was highly disturbed as a result of both the trenching and subsequent nesting activities of burrowing birds. Gibbs (1994) made recommendations for future systematic investigation on Beacon Island because the sites had been seriously disturbed and their locations were then well known.

\section{9 and 2001 Field Seasons}

The degree of prior human and ongoing disturbance by burrowing birds, together with the risk of future vandalism, led to the decision to fully excavate the burial site in 1999 (Pasveer 2000: 5). An excavation grid was set up and Gibbs' 1994 squares were reopened and extended $0.5 \mathrm{~m}$ south (Figure 2) (Pasveer 2000). Squares were excavated in $5 \mathrm{~cm}$ levels and all material was sieved with nested 3 and $5 \mathrm{~mm}$ screens. Bulk soil samples were collected and Munsell soil colour and $\mathrm{pH}$ readings were taken for most levels. The $\mathrm{pH}$ levels recorded in the field ranged between 5 and 6 , but these measures were subsequently found to be erroneous; reanalysis of the bulk soil samples showed that the $\mathrm{pH}$ actually ranged between 8.5 and 10 (Franklin 2001). The soil's high calcium carbonate content favours bone preservation and reflects this level of alkalinity (Hunt and Gilkes 1992).

The excavated area was now found to include five individuals (three adults and two children) who had been laid against each other within a circular pit (Figure 2). These individuals were designated SK7, SK8, SK9, SK10 and SK11 (Figure 3). The bones of the five individuals were in various stages of preservation and some (particularly SK10) were in very poor condition. The crania identified in 1994

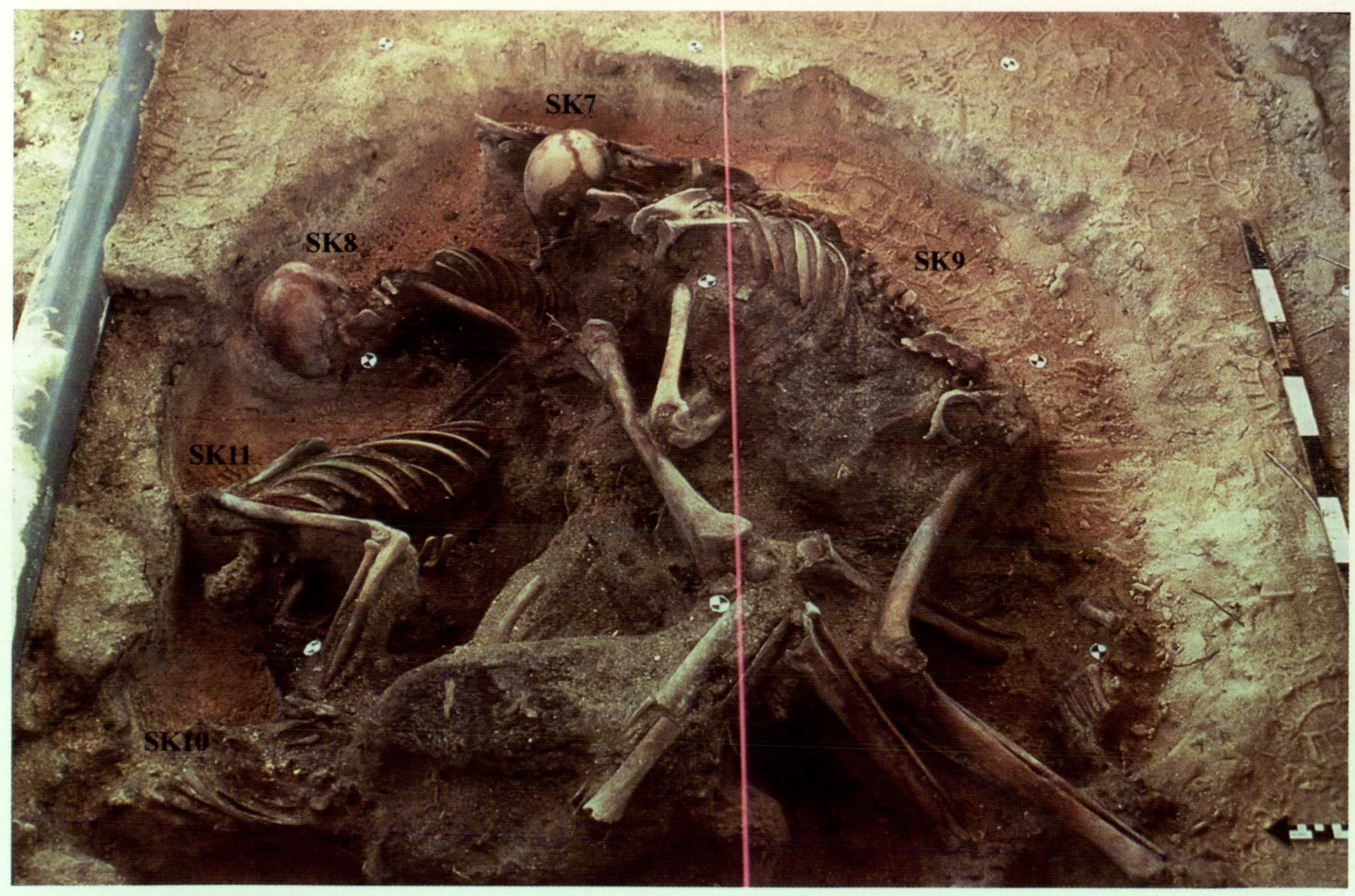

Figure 3 Four of the individuals uncovered in situ during the 1999 excavations; the bones of SK9 were removed at an earlier stage of excavation. (Photo courtesy of the Western Australian Maritime Museum). 
Table 1 Outlines and descriptions of the Batarin multiple burial skeletal material.

\begin{tabular}{ll} 
Individual & General Description \\
\hline "SK5 / SK11 & Adult: damaged cranium + partially incomplete postcranial skeleton \\
"SK6 / SK10 & Adult: damaged cranium + partially incomplete postcranial skeleton \\
SK7 & Adult: reconstructed skull and fragmentary postcranial skeleton \\
SK8 & Child: reconstructed skull and largely incomplete postcranial skeleton \\
SK9 & Child: reconstructed skull and largely incomplete postcranial skeleton \\
SK12 & Infant: deciduous and permanent teeth only
\end{tabular}

Crania and postcranial skeletons recovered and catalogued separately

(SK5 and SK6) were believed to be associated with these individuals, bringing the total sample to five skeletons (Pasveer 2000). The skeletal remains were found over, under, or in, a large deposit of black dense matter possibly of organic origin. The bones embedded in this deposit were left in situ and those removed were poorly preserved (Pasveer 2000). Later in 2001, the black deposit was excavated (see Paterson and Franklin 2004) and 16 deciduous and 2 permanent teeth were discovered underneath. This, the sixth individual recovered from the multiple burial, was designated SK12.

\section{MATERIALS AND METHODS}

The present study examines the human skeletal material recovered from the single multiple burial excavated during expeditions to Beacon Island in 1994, 1999 and 2001. One of the objects of this study has been to try and refer particular materials to known individuals in the burial. To this end age, sex and stature have been computed even when the material has been limited. The material is briefly listed in Table 1; the methods used for aging, sexing, stature estimation and pathology are described below.

A multifactorial technique of documenting age changes in dental development, eruption (Ubelaker 1999) and attrition, and also epiphyseal union and suture closure, was used for assigning individuals into one of the following categories: Child (deciduous teeth present), Sub-Adult $(<20$ years aged by dentition), Young Adult $(20-34$ years), Middle Adult (35 - 49 years) and Old Adult $(50+$ years). Sex determination was largely based on Giles and Elliot (1963), the 'Workshop of European Anthropologists' (WEA 1980), and Buikstra and Ubelaker (1994). Both cranial and postcranial metrical and non-metrical sexual characteristics were examined; however the paucity of os coxae bones meant that the cranium was the skeletal element mainly used for sex and age diagnoses.

The stature of adult individuals was assessed using the tables devised for 'Whites' by Trotter (1970). Due to the broken and incomplete condition of many of the long bones, original lengths of the tibia, humerus and radius are reconstructed and estimated according to the method outlined by Muller (1935). Statures are calculated from all available long bones and only the most reliable estimates are listed (e.g., lower before the upper limb bones). Stature ranges are estimated after consideration of variation in both reconstructions of fragmentary bones and stature regression equations. Palaeopathological diagnoses were made according to the criteria outlined in Ortner and Putscher (1981), Iscan and Kennedy (1989), and Buikstra and Ubelaker (1994). Each bone from the Batavia sample was examined macroscopically, with a hand lens and from radiographs of selected bones.

\section{RESULTS}

The basic description of the bones, estimated personal age, assigned sex, estimated stature, and any observed pathology and trauma of the skeletal material recovered from the multiple burial are outlined in this section.

The crania and postcranial skeletons of SK5/SK11, and SK6/SK10 were recovered at different times. The crania and postcranial skeletons were thus only able to be tentatively associated on the basis of morphological assessment (size and development of muscle attachments and metrical dimensions). On this basis, the cranium of SK5, which has weak development of muscle attachments, has been associated with the slender postcranial skeleton of SK11; the cranium of SK6, which has large areas of muscle attachment (mastoid processes and nuchal region of occipital bone), and is metrically larger than SK5, has been associated with the larger, more robust postcranial skeleton of SK10.

\section{SK5 / SK11}

This cranium (SK5) and incomplete postcranial skeleton (SK11) is significantly damaged. Two of the larger parts of the cranium are the frontal and parietal bones and there are fragments of the occipital and temporal bones. Most of the sphenoid bone is missing, as is the basilar part of the occipital region. The facial bones are significantly damaged and fragmented. There is no palate and only two small pieces of the maxilla are present. Fragments of both clavicles and scapulae were recovered. The 
right humerus, radius and ulna are missing. The left humerus, radius and ulna are in good condition with only slight damage to the proximal and distal ends. Ribs 1-11 of the left side are relatively well preserved. Parts of most vertebrae were recovered although their bodies are missing. The left femur, tibia and fibula are in good condition but have some damage to the proximal and distal ends. Only a few small pieces of the right tibia were recovered. Nearly all of the hand and foot bones were recovered.

Dental attrition and sutural closure suggest a middle adult, c. 35 to 49 years of age. The form and size of the nuchal crest, mastoid process and the glabella indicate indeterminate sex (Buikstra and Ubelaker 1994). Although damaged, discriminant function sexing of the cranium was possible, and implied male sex (Giles and Elliot 1963). The radial head diameter $(25 \mathrm{~mm})$ is characteristically male (Berrizbeitia 1989), and the long bones are large but with relatively weak muscle attachments, overall they are more masculine than feminine. On balance, cranial and postcranial morphology indicate a probable male sex. Stature was assessed as approximately $1.74 \mathrm{~m}$ (range $1.67 \mathrm{~m}-1.82 \mathrm{~m}$ ) from the reconstructed length of the left tibia.

The dentition presents no apparent macroscopic evidence of enamel hypoplasia or caries, but there appears to be some abnormal loss of the alveolar bone of the right maxilla. This resorption may have resulted from periapical abscesses or tooth loss (Ortner and Putschar 1981). The postcranial skeleton presents evidence of traumatic episodes. The shaft of the left ninth rib was broken near the costal angle. This injury appears to have occurred a significant time before death as the rib has healed, but at an obviously abnormally acute angle. The shaft of the left ulna has an area of abnormal bone thickening (periostitis) just superior to the level of the nutrient foramen. The abnormality was initially thought to be a healing or healed mal-aligned fracture, but radiographs show no evidence of a fracture healed or otherwise. The damage to the ulna could be the result of an injury not sufficient to actually break the bone, but enough to have caused blood vessel haemorrhaging, resulting in a subperiosteal haematoma (inter-membrane bleeding and abnormal calcification between the periosteum and endosteum).

On the basis of the osteological assessment, there is no evidence of trauma, which could have contributed to death.

\section{SK6 / SK10}

This skeleton is also significantly damaged and largely incomplete. The largest pieces of the cranium (SK6) include most of the facial region, the zygomatic and sphenoid bones, the mastoid and parts of the temporal bone of the left side (Figure
4). Other cranial fragments include parts of the right orbit, occipital and zygomatic bones. The maxilla and palate are complete, but there is no mandible. Only a small proportion of the fragmented postcranial skeleton (SK10) was recovered. The left and right humeri are both fragmented and incomplete. The right radius and ulna are well preserved and mostly complete. There is some damage to the distal regions of the left radius and ulna. A few ribs, lumbar vertebrae and sacral fragments were recovered, but there are no pelvic bones. The lower limb bones are largely fragmented and incomplete. Most of the hand and foot bones were recovered.

Dental attrition and sutural closure suggest a middle adult, c. 35-49 years of age. The form of the mastoid process and the glabella indicate male sex (Buikstra and Ubelaker 1994) and discriminant function sexing of the cranium also suggests male sex (Giles and Elliot 1963). The radial head diameter $(23.25 \mathrm{~mm})$ is characteristically male (Berrizbeitia 1989), and the right radius and ulna are large and robust with well-developed muscle attachments, traits that typify a male individual. Cranial and postcranial morphology imply male sex. Stature was assessed as approximately $1.79 \mathrm{~m}$ (range 1.75 $\mathrm{m}-1.83 \mathrm{~m}$ ) from the length of the right radius.

The dentition presents no apparent macroscopic evidence of enamel hypoplasia, caries or dental disease. However, apparently before death, the upper right central incisor appears to have been

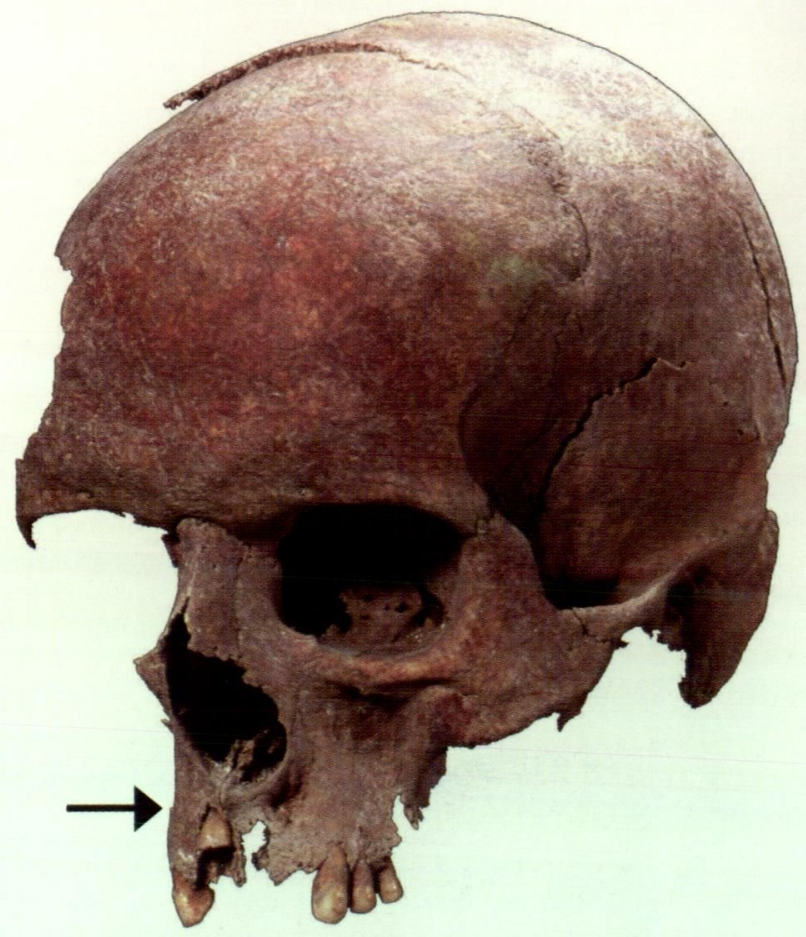

Figure 4 The damaged cranium of SK6: arrow indicates impacted upper right central incisor. (Photo by Patrick Baker, Western Australian Maritime Museum). 
forced through the alveolar process into the nasal cavity (Figure 4). Other than the localised area of intrusion, neither the incisor nor the surrounding maxillary bone appears to be significantly damaged. There is no apparent evidence of postcranial trauma, but there is some disparity between the left and right ulnae and radii, particularly in areas of muscle or ligament attachments and shaft circumference and tuberosity diameters. The right radial tuberosity is better developed and larger than on the opposing side. This asymmetrical development may be the result of adaptations associated with the favoured use of the right side. The terminal and middle phalanges of the fourth digit of the right foot are fused. The aetiology of this is uncertain, but it could be congenital, or the result of trauma or occupational activities.

Although the osteological assessment indicates some evidence of trauma in the cranium, it appears unlikely to have contributed to death.

\section{SK7}

This is the most complete skeleton recovered from the 1999 excavation (Figure 5). The skull is largely complete and well preserved. The maxillary region inferior to the right infraorbital foramen is damaged and there is no palatine bone. There is also some damage to the left sphenoid bone. Although fragmentary, most postcranial skeletal elements are represented, but the proximal and distal ends of most of the long bones are damaged to some degree. Of the pelvis only small fragments of the left acetabulum and greater sciatic notch were found. The bodies of all vertebrae are missing and only the arches were found.

Dental development, attrition and sutural closure suggest a young adult, c. 20-34 years of age. The form of the nuchal crest, mastoid process and mental eminence all indicate male sex (Buikstra and Ubelaker 1994). Discriminant function sexing of the cranium also indicated male sex (Giles and Elliot 1963). The left femoral head is mostly complete and the diameter $(49.75 \mathrm{~mm})$ is characteristically male (Stewart 1979). The shape of the greater sciatic notch indicates a probable male morphology (Buikstra and Ubelaker 1994). Cranial and postcranial morphology clearly indicate male sex. Stature was assessed as approximately $1.76 \mathrm{~m}$ (range $1.71 \mathrm{~m}-1.83 \mathrm{~m}$ ) from the reconstructed length of the right tibia. The dentition presents no apparent macroscopic evidence of enamel hypoplasia or dental disease and the only carious tooth appears to be the lower right second premolar, which is also broken midway through the mesial cusp.

Evidence of trauma is not apparent, but there is some disparity present between the left and right clavicle and humeri, particularly in areas of muscle or ligament attachment and shaft circumference and diameters. The conoid tubercule of the left clavicle is more developed and larger than the opposing side. The mid-shaft diameter and least circumference of the left humerus are larger than the right side. This asymmetrical development
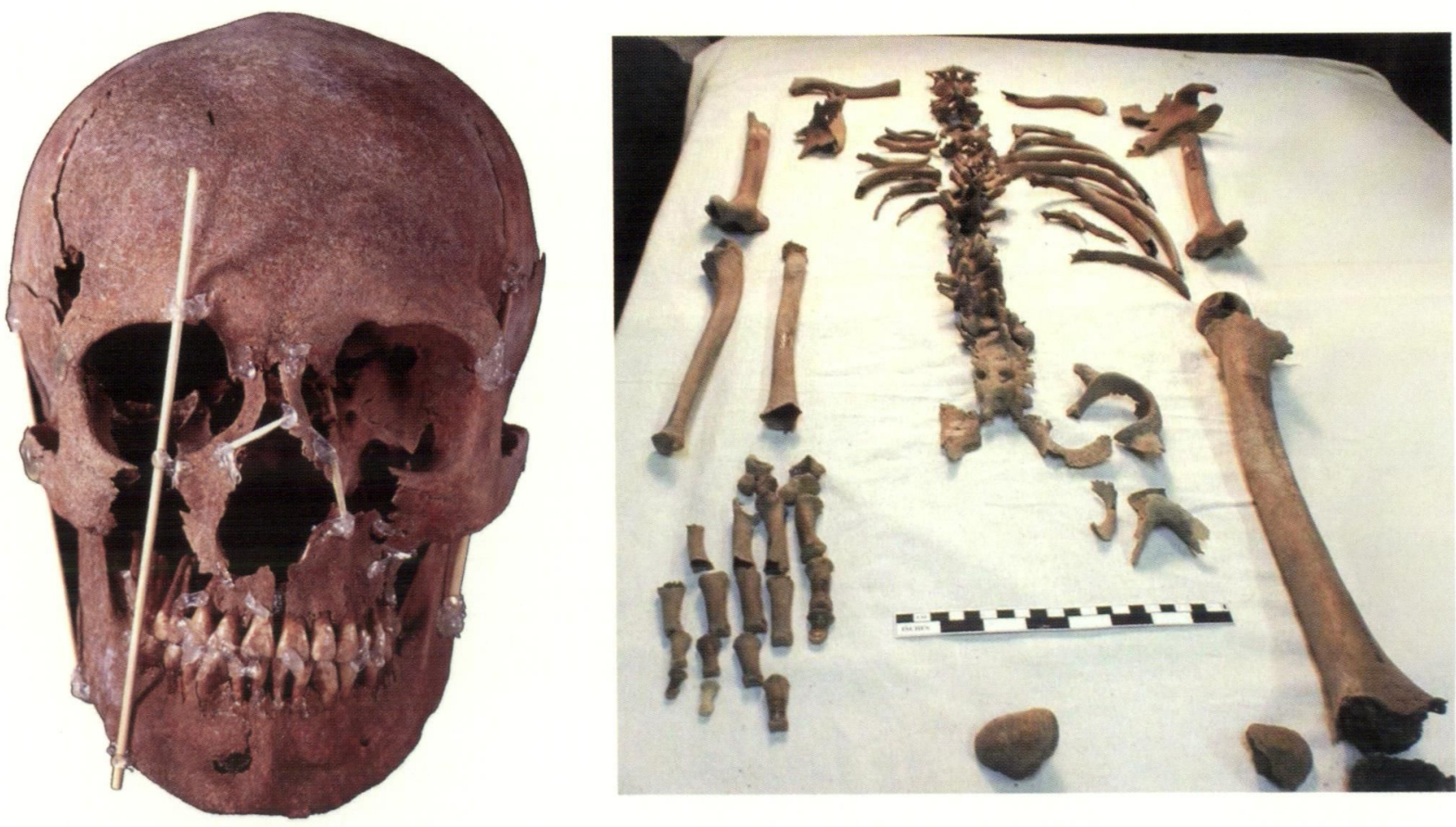

Figure 5 Reconstructed skull and postcranial skeleton of SK7. (Skull photo by Patrick Baker, Western Australian Maritime Museum). 
might be the result of mechanical changes associated with the favoured use of the left side. Radiographs of the right tibia revealed the presence of at least three Harris lines approximately 20 to 25 $\mathrm{mm}$ from the distal articular surface. One of the three lines is faint and very short, approximately 15 $\mathrm{mm}$. The remaining two lines are clearly visible and extend at least halfway across the tibial shaft.

Approximately one-quarter of the distal end of the left tibial shaft is markedly roughened and porous, a pattern indicating a deficiency in osteoid production and calcium deposition (Figure 6) (Collins 1966; Aufderheide and Rodriguez-Martin 1998). The shell of lamellar new bone on the surface appears to be attached to the original cortex by a web of more porous bone, which has completely obliterated the nutrient foramen. This implies some metabolic disturbance affecting the individual in the immediate antemortem period and this has been tentatively identified as possibly being scurvy, a condition caused by a deficiency of vitamin C (Aufderheide and Rodriguez-Martin 1998).

Scurvy was common in sailors of the period, and is suggested because scorbutic individuals are susceptible to subperiosteal haemorrhaging due to aberrant blood capillary formation. When the haemorrhage is of a substantial size the bone often has a more porous structure (Aufderheide and Rodriguez-Martin 1998: 311; Ortner et al. 1999; Buckley 2000). Since bleeding and the resulting changes to surrounding bone tissue tend to occur in regions under mechanical stress (Ortner et al. 1999: $322)$, the obliteration of the tibial nutrient foramen is probably not unusual. Similar scorbutic changes in the lower long bones have been reported in individuals from a $17^{\text {th }}$ century Dutch whaling station at Spitsbergen (Maat 1981) and the $14^{\text {th }}$ century Crow Creek massacre site in South Dakota (Willey and Emerson 1993).

The osteological assessment does not reveal any evidence of trauma, which could have contributed to death.

\section{SK8}

The skull and some of the postcranial skeleton of this individual were recovered. The skull is significantly damaged, although largely complete, and was reconstructed by Dr Stephen Knott. There is some damage to the right facial bones, particularly the right vomer and maxilla. There is no palate. Most internal bones are missing and parts of the right lateral body and condyle of the mandible are damaged. Fragments of the atlas and cervical vertebrae are present. Fragments of both clavicles, parts of the right scapula and many rib fragments are present. Both the proximal and distal end regions of the left and right humeri are missing and only the shaft remains. The distal regions of the left radius and ulna are also damaged. Some of the phalanges of the left hand were recovered. No postcranial skeletal elements below the pelvis were examined as they are embedded in a dense soil

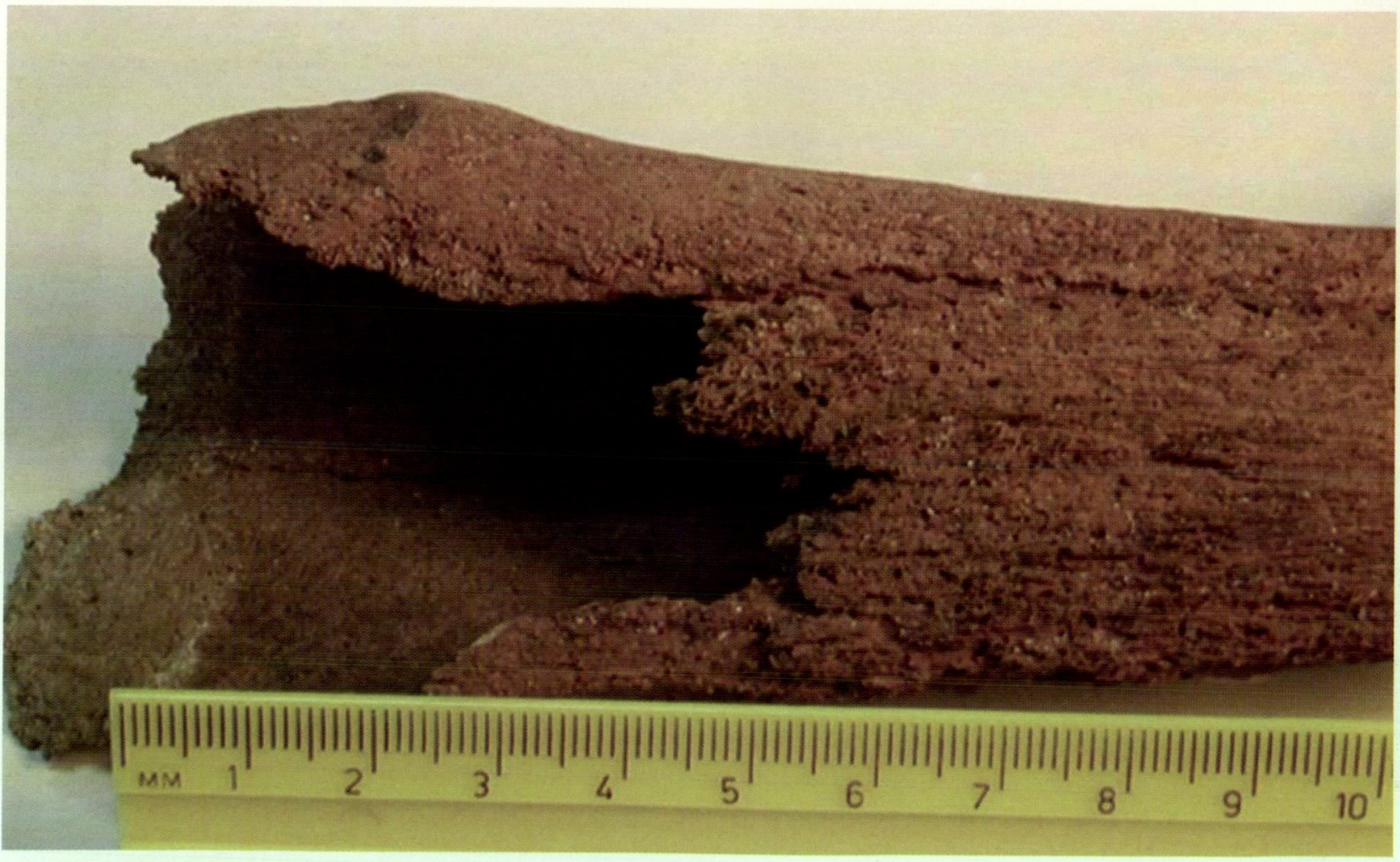

Figure 6 Distal left tibia of SK7 displaying marked porosity. 
feature which has only recently been excavated in a solid block (Paterson and Franklin 2004).

Dental development and sutural closure suggest a sub-adult, $<20$ years (c. 15-16 years) of age. It was not possible to conclusively determine the sex of this immature and fragmented skeleton, but the base of the symphysis and the body shape of the mandible display some features noted by Loth and Henneberg (2001) to be male characteristics. The chin region of SK8 extends abruptly downwards and squares off at the base of the symphysis and the transition to the lateral body is sharply angled. These features are typical male characteristics, but more definitive sex determination would require contemporary metrical data from a juvenile Dutch population or DNA analysis. Stature was assessed as approximately $1.51 \mathrm{~m}$ (range $1.49 \mathrm{~m}-1.53 \mathrm{~m}$ ) from the reconstructed length of the left radius. The dentition presents no apparent macroscopic evidence of enamel hypoplasia, caries or dental disease.

No apparent evidence of abnormalities was detected in the skeleton. On the basis of the osteological assessment there is no evidence of trauma, which might have contributed to death.

\section{SK9}

The skull of this juvenile individual was crushed by the weight of overlying soil and the postcranial skeleton is largely incomplete (Figure 7). The skull, reconstructed by Dr Stephen Knott, is fairly complete, but parts of the right orbit and nasal cavity, lacrimal bone and maxilla are missing or damaged. Most internal bones are also missing and the mandible is fractured through the middle of the symphysis. Dental development suggest a child; c. 5-6 years of age. It was not possible to conclusively determine the sex or reconstruct stature from the immature skeleton. The dentition presents no apparent macroscopic evidence of enamel hypoplasia, caries or dental disease.

There was no evidence of trauma in the skeletal remains, which might have contributed to death.

\section{SK12}

The only remains of this individual that were recovered are the permanent left first molars and all of the deciduous teeth, except for the lower incisors and left canine. Dental development is of a child, c. 8-9 months of age, notably because initial cusp formation of the first permanent molars has occurred and their coalescence is nearly complete. Sex determination was not possible. There is no evidence of enamel hypoplasia in any of the teeth, although there is some noticeable developmental disparity with the left side slightly less developed than the right. This is within a normal range of variation and is not pathological. There is no evidence of occlusal function.

\section{DISCUSSION}

The demographics and health status of the individuals recovered from the multiple burial are summarised (Table 2) and discussed below.

\section{Demographics}

All of the adults recovered from the multiple burial were assessed as probable males. The subadult individual (SK8) is also tentatively classified as male, but the sex of the one child (SK9) and infant (SK12) remain unknown. The bias towards males is expected, given that approximately five men for every woman were murdered by Cornelisz and his accomplices (Drake-Brockman 1963: 50). The Batavia's complement comprised mostly males,
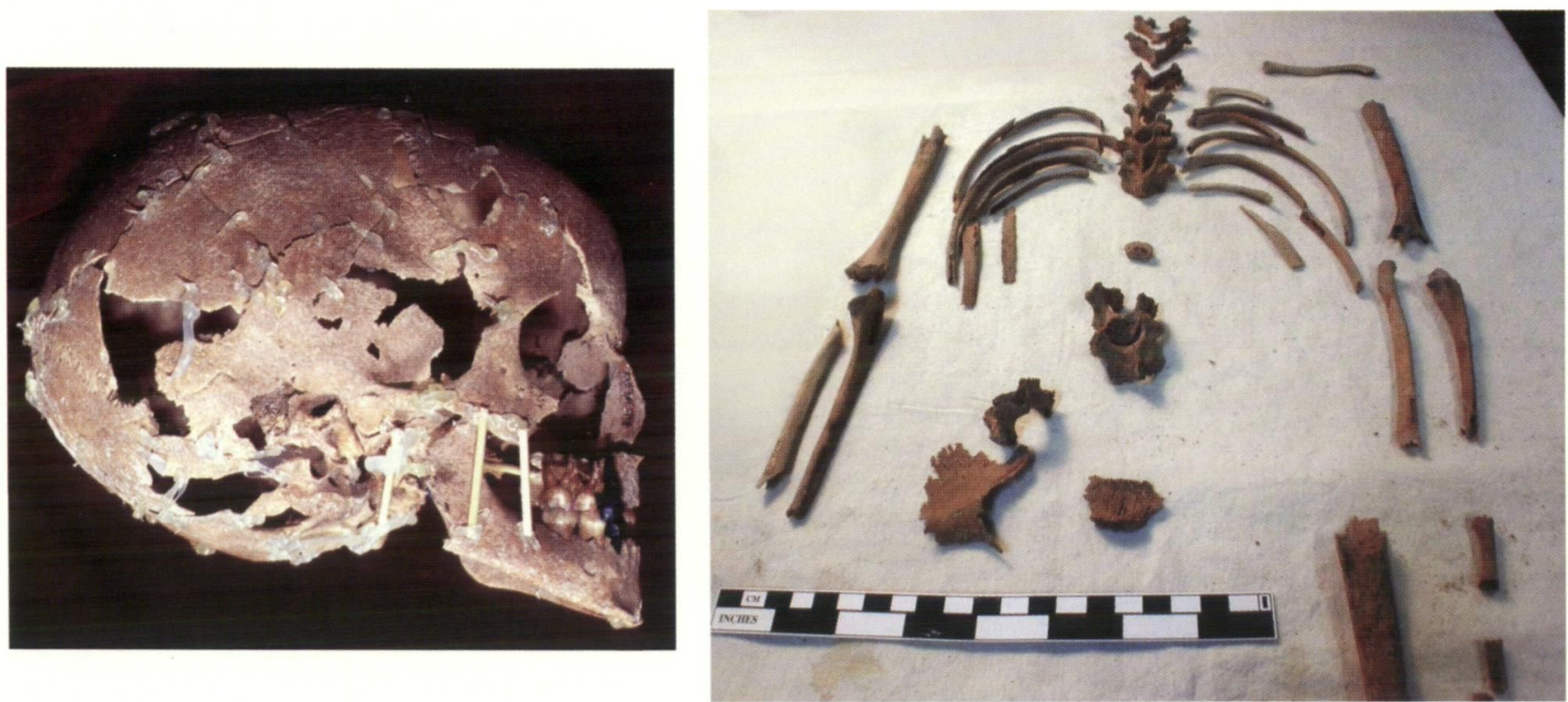

Figure 7 Reconstructed skull and postcranial skeleton of SK9. (Skull photo by Patrick Baker, Western Australian Maritime Museum). 
Table 2 Main features of the Batavia skeletal material including proposed associations (/) of cranial and postcranial skeletons.

\begin{tabular}{|c|c|c|c|c|c|}
\hline Individual & Description & $\begin{array}{l}\text { Assigned } \\
\text { Sex }\end{array}$ & $\begin{array}{c}\text { Age } \\
\text { Range }\end{array}$ & $\begin{array}{c}\text { Mean } \\
\text { Stature }\end{array}$ & Trauma/Abnormalities \\
\hline SK5 / SK11 & $\begin{array}{l}\text { Damaged cranium + } \\
\text { postcranial skeleton }\end{array}$ & Male & $35-49$ yrs & $1.74 \mathrm{~m}$ & $\begin{array}{c}\text { Healed rib fracture and } \\
\text { subperiosteal haematoma (ulna) }\end{array}$ \\
\hline SK6 / SK10 & $\begin{array}{l}\text { Damaged cranium + } \\
\text { postcranial skeleton }\end{array}$ & Male & $35-49 \mathrm{yrs}$ & $1.79 \mathrm{~m}$ & $\begin{array}{l}\text { Facial damage and skeletal } \\
\text { asymmetry (upper limb) }\end{array}$ \\
\hline SK7 & $\begin{array}{l}\text { Skull + postcranial } \\
\text { skeleton }\end{array}$ & Male & $20-34$ yrs & $1.76 \mathrm{~m}$ & $\begin{array}{c}\text { Harris lines and } \\
\text { pathological tibia (scurvy?) }\end{array}$ \\
\hline SK8 & $\begin{array}{l}\text { Skull + postcranial } \\
\text { skeleton }\end{array}$ & Male & $15-16$ yrs & $1.51 \mathrm{~m}$ & $\begin{array}{c}\text { No evidence of trauma } \\
\text { or abnormalities }\end{array}$ \\
\hline SK9 & $\begin{array}{l}\text { Skull + postcranial } \\
\text { skeleton }\end{array}$ & $?$ & $5-6$ yrs & N/A & $\begin{array}{c}\text { No evidence of trauma } \\
\text { or abnormalities }\end{array}$ \\
\hline SK12 & $\begin{array}{l}\text { Deciduous + } \\
\text { permanent teeth }\end{array}$ & $?$ & $8-9$ mo & N/A & $\begin{array}{l}\text { Some left/right disparity } \\
\text { in dental development }\end{array}$ \\
\hline
\end{tabular}

*yrs = years; mo = months

who were regarded by the mutineers to be the greatest threat. As such, males were the primary targets in the initial murders. In contrast, women were perceived as a lesser threat and many were kept alive to serve as unwilling concubines for the mutineers (van Huystee 1998). The age at death of the sample appears to range from approximately 8 months to no older than 49 years of age. Even though only a small sample was available for study, the age demographics, in particular the apparent lack of older adults (50+ years of age), is not unusual given the shorter life expectancy in $17^{\text {th }}$ century Europe (Jacobs 1991). Furthermore, the chances of a career sailor serving aboard a VOC vessel past 50 years of age would be slim, especially considering shipboard conditions of the early $17^{\text {th }}$ century (see Bruijn et al. 1987).

\section{Dental health}

Even taking the small sample size into consideration, the dental health of the Batavia sample as a whole is assessed as generally good. There were relatively few examples of dental diseases such as caries, periodontal disease or calculus accumulation. Some of the older adults in the Batavia sample displayed evidence of antemortem tooth loss, often of the first molar. This may have been the result of caries or severe wear exposing the pulp cavity, leading to an infection of the supporting tissue (Ortner and Putschar 1981).

\section{Trauma}

Of the multiple burial individuals, the postcranial skeleton of SK11 displays evidence of a healed fracture of the left ninth rib and a subperiosteal haematoma of the left ulna. The relatively poor alignment of the rib fracture may attest to low quality or no medical attention to the injury, although the bone has healed well, which is a general indicator of good health (Webb 1989). The subperiosteal haematoma of the left ulna most probably resulted from a fall or a blow to that arm. The interpretation of traumatic markers often affords some insight into certain factors concerning the lifestyle of the afflicted individuals (Roberts and Manchester 1995). For SK5/SK11 it was only possible to infer that this individual may have led a physical lifestyle where occupational injuries were common. Other samples of $17^{\text {th }}$ century mariners also reputedly display similar evidence of having led physical lifestyles (cf. Maat 1981: 169). The upper right central incisor of the cranium of SK6 has been forced through the alveolar process into the nasal cavity. This likely resulted from a heavy blow against the teeth, but it is not possible to ascertain whether the trauma is the result of violence or accident. It is important to note that the prevalence of trauma in the Batavia sample as a whole may be under-represented due to the small and fragmented nature of the skeletal assemblage.

\section{Nutritional related deficiencies}

The tentative diagnosis of scurvy in SK7 is the only possible nutrition-related deficiency in the sample. One of the primary causes of a high mortality rate aboard VOC vessels was disease, particularly scurvy, which could take a high toll on a crew already undernourished on departure (Gaastra and Bruijn 1993: 203). Efforts were made to combat the illness by sending along less perishable fruits or fruit extracts, and the Cape of Good Hope was officially founded as a supply base for fresh food and water in 1652 (Bruijn et al. 1987). The little or no evidence of scurvy in this sample may indicate that the provisioning of less perishable foods and the stop over at the Cape (which the Batavia made) was helping to combat the disease, although the sample is only a small fraction of the 
ship's complement, and much of the recovered material is poorly preserved.

\section{Non-specific stress indicators}

No enamel hypoplasia was detected in the dentition of the sample. Relatively small and faint Harris lines were present on SK7, which may indicate a period of childhood nutritional deficiency, stress or illness (Rathbun 1987; Hughes et al. 1996). This was not uncommon in $17^{\text {th }}$ century Europe (see Maat's 1984 analysis of $17^{\text {th }}$ to $18^{\text {th }}$ century Dutch whalers). The relatively fragmented, incomplete and poor condition of a large proportion of the postcranial skeletons in the multiple burial may be a factor in the possible under representation of the frequency of Harris lines. A lack of Harris lines does not indicate an absence of disease; the aetiology and multiple factors contributing to the appearance of these skeletal markers is unclear and should not be regarded as the sole indication of a population's health (Hughes et al. 1996: 129).

\section{Occupational stressors}

Modern clinical data has established that certain activities can cause osteoarthritis and other skeletal changes (Roberts and Manchester 1995). Mechanical factors are obviously important in the production of pathological skeletal changes, but to assume that these changes are indicative of occupational stressors is probably an oversimplified view (Waldron 1993: 73). On SK7 and SK10 some asymmetry was observed in shaft diameters and the size of muscle or ligament attachment sites between the left and right sides of the upper skeleton. Any habitual activity performed with a side-preference can place extra stress on that specific proportion of the anatomy and can contribute to asymmetrical skeletal development (Wienlar and Wood 1988; Capasso et al. 1999). Some bending of the spinous processes of the vertebrae of SK7 and SK11 was observed, but this is not considered to be pathological and might be an occupational change related to side-preference.

\section{Interpretation of the multiple burial}

From Pelsaert's Journal it is apparent that there are at least two groups of murder victims buried in multiple graves on Beacon Island; the first was a group of sick individuals, the second the Predicant's family (Drake-Brockman 1963: 175, 186). There are, however, many other instances where multiple burials might have been made, among them the large number of people reported to have drowned attempting to swim from the wreck to land (van Huystee 1998). Below we describe two possible interpretations of the Beacon Island multiple burial. The first is that they were drowning victims, and second that they were the family of the Predicant (the Batavia's official minister) (Pasveer 2000). We conclude that both interpretations appear to be improbable from the evidence of this research. We then outline another more probable theory backed by what we offer as supportive evidence (Franklin and Freedman 2003).

\section{Drowning victims following the wrecking}

Could this multiple grave hold the remains of individuals who had died by drowning in the immediate period following the wrecking of the Batavia? The skeletal remains in the multiple burial were clearly 'roughly' thrown into the burial pit (Figure 3). It would seem most unlikely that the Batavia survivors would have abandoned their religious or social values so soon after the wrecking. While the situation was dire, it was not without hope of rescue. The VOC would soon become aware of their non-appearance and there was also the option to sail for help in the salvaged sloop (as Pelsaert did).

If the survivors were to bury their dead at that time in a multiple grave, one would certainly expect more care to have been taken in the burials rather than the clearly hasty and disrespectful interments they received. For example, a traditional Christian burial style would at the very least have the bodies orientated east-west, which the individuals buried in the multiple grave are not (Figure 3) (Gerven et al. 1981). Even when people were faced with lethal epidemics such as the 'Black Death', there are examples of burials that were organised methodically and with care (Royal Mint site, London; Margerison and Knusel 2002). A modern equivalent to the multiple burial on Beacon Island (but on a larger scale) are crude, hasty multiple graves associated with the murder of civilians in the former Yugoslavia (see Stover and Ryan 2001). The conclusion is that it would seem most unlikely that the multiple burial represents a deliberate interment of those who died by drowning or illness following soon after the wrecking of the Batavia.

\section{The Predicant's family}

The Predicant's family included his wife, maid and six of their seven children; two girls, three boys and a baby. The historical accounts of the murder of the Predicant's family describe 'the beating in of the skull of the wife and that of one of the children' (Drake-Brockman 1963: 174-186). The individual burials discovered in the 1960s all display evidence of cranial damage (sharp weapon trauma and depressed fractures). On the other hand, in the Beacon Island multiple burial there is no apparent evidence of these types of trauma. Also, the number of individuals in the Predicant's family and their stated ages and sexes clearly do not match those individuals from the burial pit (see Table 2) 
A likely interpretation: early 'sick' victims of the massacre

On July $10^{\text {th }}$ or $12^{\text {th }}$ (the dates are inconsistent in Pelsaert's Journal) the early 'sick' murders occurred. The victims were Passchier van den Enden (a gunner), Jacob (Jacop) Hendricxsz (a carpenter), Jan Pinten (an English soldier) and a cabin boy, all of whom were ill and could offer little resistance. They had their throats cut by Cornelisz's accomplices. At least one body (Jacob Hendricxsz) was dragged into a pit 'which had been made ready' (DrakeBrockman 1963: 183-199). It would be reasonable to assume that all four bodies were disposed of in the ready-made pit simultaneously.

The three adult individuals killed by Jan Hendricxsz (the gunner, soldier and carpenter) would all have been adult males. There are what appear to be three male adults (SK5/SK11, SK6/ SK10 and SK7) interred in the burial pit. The apparent lack of violent trauma on all of the skeletons is consistent with historical accounts of the throats of these victims being cut rather than having their heads beaten in, but does not rule out other sorts of injuries undetectable in the absence of soft tissue. The poor preservation of the skeletal material recovered from the Beacon Island multiple burial could explain the absence of markers indicative of someone having their throat cut. Interestingly, the mutineers asked to spare the carpenter's life, but Cornelisz reportedly replied, "...that he was half lame and that he must go" (Drake-Brockman 1963: 183). If by 'lame' Cornelisz meant that the carpenter was physically disabled in some manner, it is worth considering that SK7 very likely had some degree of pain and/or movement impediment due to the pathological condition of his left tibia (Maat 1981; Aufderheide and Rodriguez-Martin 1998).

Skeleton SK8 was estimated to be less than 20 years old (probably between 15 and 16 years of age), close to the typical age of a cabin boy. The sex of this individual is uncertain, but the skeleton does display some male characteristics that offer some credibility to assigning male sex. After reconciling historical accounts with biological evidence, it would seem reasonable to postulate that the four individuals described above were those recovered from the multiple burial pit.

There are two other individuals (SK9 and SK12) represented in the multiple burial. SK9 is of a child of unknown sex, approximately 5 to 6 years of age. Approximately two days earlier than the murder of the gunner, carpenter and soldier (July $8^{\text {th }}$ ), Jan Hendricxsz strangled the six-year-old daughter of Hans Hardens (Drake-Brockman 1963: 183). SK9 is approximately the same age and does not display any visible evidence of trauma. There is no mention of how the body was disposed, but with the pit available the body might well have been buried there as well. This murder took place before the first 'public' murder on July $14^{\text {th }}$ (Drake-Brockman 1963: 115), so the body would have to have been concealed until it could be permanently disposed. SK12 is an infant approximately 8 to 9 months of age. This individual cannot be directly accounted for from historical accounts, but there were several children of unspecified ages murdered and how their bodies were disposed of is not always recorded. It is possible that the infant could be the 'suckling' child of Maijken Cardoes, who was strangled by Salomon Deschamps on 20 July; but this seems unlikely because the infant was recovered from the bottom of the burial, and we would have expected it to have died before 10-12 July (cf van Huystee 2000; Paterson and Franklin 2004).

\section{CONCLUSIONS}

This study describes the age, sex, stature, trauma and pathology of the six individuals recovered from a multiple burial related to the Batavia mutiny on Beacon Island. The burial of those individuals was not systematic, and instead represents a hasty interment in the early part of the mutiny. We postulate that the remains of four of the interred can be reconciled with historical accounts and could be those of a group of sick individuals who were amongst the early victims of the massacre. In addition, two sub-adult skeletons were recovered. The six year old may be the child strangled two days before the other individuals were killed. The infant could not be directly reconciled with historical accounts, but a number of infants are known to have been killed at various times during the mutiny.

\section{ACKNOWLEDGEMENTS}

The authors would like to thank the staff (past and present) of the Western Australian Maritime Museum, including Myra Stanbury, Juliette Pasveer, Corioli Souter and Patrick Baker, for access to the Batavia material and for permission to reproduce photographs. Specialised technical advice was provided by Dr Alanah Buck, Dr Stephen Knott (both of the QE II PathCentre), and Professor Sandra Bowdler (of the Centre for Archaeology, The University of Western Australia), and was much appreciated. Special thanks go to Dr Bruce Stock of Sir Charles Gairdner Hospital who kindly donated his time and expertise to take the radiographs. We would also like to thank Professor George Maat, Anatomy Department, The University of Leiden, for the helpful correspondence and informative research publications. The authors thank Dr Alanah Buck and Dr Shane Burke for commenting on drafts of this paper. We would also 
like to thank Myra Stanbury for her helpful review of this paper. The preparation of this manuscript was supported financially by ARC Discovery Project Grant number DP0557157.

\section{REFERENCES}

Aufderheide, A.C. and Rodriguez-Martin C. (1998). The Cambridge Encyclopedia of Human Paleopathology. Cambridge University Press, Cambridge.

Berrizbeitia, E.L. (1989). Sex determination with the head of the radius. Joumal of Forensic Sciences 34: 1206-1213.

Bevacqua, R. (1974). Archaeological survey of sites relating to the Batavia shipwreck. Early Days (Journal and Proceedings of the Western Australian Historical Society) 7 (6): 50-78.

Bruijn, J.R., Gaastra, F.S. and Schoffer, I. (1987). DutchAsiatic Shipping in the $17^{h}$ and $18^{\text {th }}$ Centuries. Volume 1. Introductory Volume. Rijks Geschiedkundige Publicatien, Grote Serie 165. Martinus Nijhoff, The Hague.

Buckley, H.R. (2000). Subadult health and disease in prehistoric Tonga, Polynesia. American Journal of Physical Anthropology 113: 481-505.

Buikstra, J.E. and Ubelaker, D.H. (1994). Standards for Data Collection From Human Skeletal Remains. Arkansas Archaeological Survey, Arkansas.

Capasso, L., Kennedy, K.A.R. and Wilczak, C.A. (1999). Atlas of Occupational Markers on Human Remains. Edigrafital S.P.A., Teramo.

Collins, D.H. (1966). Pathology of Bone. Butterworth and Co., London.

Dakin, W. (1919). The Percy Sladen Trust Expeditions to the Abrolhos Islands (Indian Ocean). Journal of the Linnean Society London 34: 127-180.

Drake-Brockman, H. (1963). Voyage to Disaster. University of Western Australia Press, Nedlands.

Franklin, D. (2001). A Bioarchaeological Investigation of Beacon Island Land Sites and the Victims of the Batavia Mutiny. Unpublished B.Sc. Honours Thesis, School of Anatomy and Human Biology, Centre for Archaeology. University of Western Australia, Perth.

Franklin, D. and Freedman, L. (2003). A bioarchaeological investigation of Beacon Island Land sites and the victims of the Batavia Mutiny. Proceedings of the Australasian Society for Human Biology, Perth, Western Australia, 9-11 December 2002. Homo 54: 81.

Gaastra, F.S. and Bruijn, J.R. (1993). The Dutch East India Company's Shipping, 1602-1795, in a Comparative Perspective. In J.R. Bruijn and F.S. Gasstra (eds). Ships, Sailors and Spices: East India Companies and Their Shipping the $16^{\text {th }}, 17^{\text {h }}$ and $18^{\text {h }}$ Century, pp. 177-208. CIP-Gegevens Koninklijke Bibliotheek, The Hague.

Gerven, van D.P., Sandford, M.K. and Hummert, J.R. (1981). Mortality and culture change in Nubia's Batn el Hajar. Joumal of Human Evolution 10: 395-408.

Gibbs, M. (1994). Report on the Excavation of Skeleton SK5, A Victim of the Batavia Massacre of 1629 , Beacon Island, Western Australia. Department of Maritime Archaeology Report No. 112. Western Australian Maritime Museum, Fremantle.
Giles, E. and Elliot, O. (1963). Sex determination by discriminant function analysis of crania. American Journal of Physical Anthropology 21: 53-68.

Godard, P. (1993). The First and Last Voyage of the Batavia. Abrolhos Publishing, Perth.

Green, J. (1989). The Loss of the Verenigde Oostindische Companie retourschip Batavia, Western Australia 1629: An Excavation Report and Catalogue of Artefacts. British Archaeological Reports, International Series No. 489, Oxford.

Green, J. and Stanbury, M. (1988). Report and Recommendations on Archaeological Land Sites in the Houtman Abrolhos. Report - Department of Maritime Archaeology, Western Australian Maritime Museum, No. 29.

Hughes, C., Heylings, D.J.A. and Power, C. (1996). Transverse (Harris) lines in Irish archaeological remains. American Journal of Physical Anthropology 101: 115-131.

Hunneybun, B. (1995). Skullduggery at Beacon Island. Unpublished B.Sc. Honours Thesis, Centre for Archaeology. University of Western Australia, Perth.

Hunt, N. and Gilkes, B. (1992). Farm Monitoring Handbook: A Practical Down-to-Earth Manual for Farmers and Other Land Users. University of Western Australia: Nedlands.

Huystee, van M. (ed.) (1998). The Batavia Journal of Francisco Pelsaert. Trans. van Huystee M. Report Department of Maritime Archaeology, Western Australian Maritime Museum, No. 136.

Iscan, M.Y. and Kennedy, K.A.R. (eds) (1989). Reconstruction of Life From the Skeleton. Allen R Liss Inc, New York.

Jacobs, E.M. (1991). In Pursuit of Pepper and Tea: The Story of the Dutch-East India Company. Netherlands Maritime Museum, Amsterdam.

Loth, S.R. and Henneberg, M. (2001). Sexually dimorphic mandibular morphology in the first few years of life. American Joumal of Physical Anthropology 115: 179-186.

Maat, G.J.R. (1981). Human remains at the Dutch whaling station on Spitsbergen. A physical anthropological study. Proceedings of the International Symposium on Early European Exploitation of the Northern Atlantic 800 - 1700. Arctic Centre, Groningen.

Maat, G.J.R. (1984). Dating and rating of Harris's lines. American Joumal of Physical Anthropology 63: 291-299.

Margerison, B.J. and Knusel, C.J. (2002). Paleodemographic comparison of a catastrophic and attritional death assemblage. American Journal of Physical Anthropology 119: 134-144.

Muller, G. (1935). Zur bestimmung der lange beschadigter extremitatenknochen. Anthropology Anzeiger 12: 70-72

Ortner, D.J. and Putschar, W.G.J. (1981). Identification of Pathological Conditions in Human Skeletal Remains. Smithsonian Institution Press, Washington.

Ortner, D.J., Kimmerle, E.H. and Diez, M. (1999). Probable evidence of scurvy in subadults from archaeological sites in Peru. American Journal of Physical Anthropology 108: 321-331.

Pasveer, J. (2000). Archaeology, In M. Stanbury (ed.). 
Abrolhos Islands Archaeological Sites: Interim Report 5-10, Special Publication No. 5. Australian National Centre of Excellence for Maritime Archaeology, Fremantle.

Pasveer, J., Buck, A. and van Huystee, M. (1998). Victims of the Batavia mutiny: physical anthropological and forensic studies on the Beacon Island skeletons. Bulletin of the Australian Institute for Maritime Archaeology 22: 45-50.

Paterson, A. and Franklin, D. (2004). The 1629 mass grave for Batavia victims, Beacon Island, Houtman Abrolhos Islands, Western Australia. Australasian Society for Historical Archaeology 22: 71-78.

Rathbun, T.A. (1987). Health and disease at a South Carolina plantation: 1840-1870. American Journal of Physical Anthropology 74: 239-253.

Roberts, C. and Manchester, K. (1995). The Archaeology of Disease. Alan Sutton Publishing, New York.

Stanbury, M. (1998). Land archaeology in the Houtman Abrolhos. In J. Green, M. Stanbury and F. Gaastra (eds). The ANCODS Colloquium: Papers Presented at the Australia-Netherlands Colloquium on Maritime Archaeology and Maritime History, pp 101-107. Special Publication No. 3. Australian National Centre of Excellence for Maritime Archaeology, Fremantle.

Stewart, T.D. (1979). Essentials of Physical Anthropology: Especially as Developed in the United States. Charles C. Thomas, Springfield.

Storr, G. (1965). The physiography, vegetation and vertebrate fauna of the Wallabi Group, Houtman Abrolhos. Journal of the Royal Society of Western Australia 48: 1-14.

Stover, E. and Ryan, M. (2001). Breaking bread with the dead. Historical Archaeology 35: 7-25.
Teichert, C. (1946). Contributions to the geology of Houtman's Abrolhos, Western Australia. Proceedings of the Linnean Society of New South Wales 71: 145196.

Trotter, M. (1970). Estimation of stature from intact limb bones. In T.D. Stewart (ed.). Personal Identification in Mass Disasters, pp. 71-83. Smithsonian Institution, Washington D.C.

Tyler, P. (1970). The Batavia mutineers: evidence of an anabaptist 'Fifth Column' within $17^{\text {th }}$ Century colonialism? Westerly 4, December: 33-45.

Ubelaker, D.H. (1999). Human Skeletal Remains: Excavation, Analysis, Interpretation. $3^{\text {rd }}$ Ed. Taraxacum Press, Washington.

Waldron, H.A. (1993). The health of the adults. In T. Molleson and M. Cox (eds). The Spitalfields Project: Volume 2 - The Anthropology, pp. 67-89. Council for British Archaeology Report Number 86, London.

Webb, S.G. (1989). The Willandra Lakes Hominids. Department of Prehistory, Research School of Pacific Studies, Canberra.

Weinlar, C.W. and Wood, J.E. (1988). Osteological individuality indicative of migrant citrus laboring. Journal of Forensic Sciences 33: 562-567.

Willey, P. and Emerson, T. (1993). The osteology and archaeology of the Crow Creek massacre. Plains Anthropologist 38: 227-269.

Workshop of European Anthropologists (1980). Recommendations for age and sex diagnosis of skeletons. Journal of Human Evolution 9: 517-554.

Manuscript reccived 3 May 2005; accepted 13 September 2005 